\title{
Methods for improving the nutritive value of fibrous feed: treatment and supplementation
}

\author{
M Wanapat 1, M Chenost 2, F Munoz 3, C Kayouli 4 \\ 'Department of Animal Science, Faculty of Agriculture, Khon Kaen University, Khon Kaen 40002, Thailand: \\ 2INRA Clermont-Ferrand/Theix. 63122 St Genes Champanelle. France. 3 SIA DGA. Apartado 727, 50080 \\ Zaragoza, Spain:4/NAT, 43 avenue Charles Nicolle, 1002 Tunis, Tunisia.
}

Summary - Once harvested and stored it is important to optimize the use of poor quality roughages (PQR) by ruminants. This can be done through treatments, that improve the quality of the roughage per se and through appropriate supplementation and feeding techniques, whether the PQR is treated or not. A tremendous amount of work has been done over the last twenty years at both research and development level. This paper recalls the basic principles and the main technologies available for optimizing the digestive use of poor quality roughages. It also discusses and tries to highlight the advantages and drawbacks of transferring them in practice, with particular emphasis on urea treatment and multinutritional blocks. Two main steps should be considered: (a) feeding the microorganisms of the rumen in such a way that the growth and activity of cellulolytic strains are favoured. This is achieved either by a so called catalytic supplementation or by a treatment and (b) feeding the host animal the necessary nutrients that would ensure a satisfactory nutritional status (including its intake capacity which is generally low with such a type of basal diet) to meet its production requirements. Provided some key rules, described in the paper, are observed, the "urea treatment" is technically perfectly adapted to small production units, at both the individual and the cooperative level. Much practical field experience has been acquired now in an extremely wide range of agro-ecological and sociological conditions. Sealing is less a concern than with an anhydrous ammonia treatment and is not necessarily important when large quantities of plant material are treated (self covering). Locally available material such as banana leaves or sheaths, seko mats, banco, mud and old plastic bags proved to be successful on farm scale. Animal response to urea treatment is similar to that observed with anhydrous ammonia treatment achieved at the same alkali level. This response is optimum with moderatly yielding animals (whose diet consists essentially of PQR) making them the "target animals". The "catalytic" supplementation supplies Non Protein Nitrogen (NPN) (namely urea) and minerals (the "strategic" supplements). This supplementation hardly covers the maintenance requirements of the animals. The carrying medium is either liquid, such as the molasses-urea mixtures used in Egypt or solid, in the form of multinutritional blocks, now used in villages in many countries. Practical examples are given. Thanks to these blocks it is possible to incorporate local agro-industrial by-products that, otherwise, would be under-utilized. The supplementation required for higher levels of production should, at any time: (a) not endanger the cellulolytic rumen ecosystem (this prerequisite is of particular importance with treated roughages for not losing the benefit of the treatment), by providing digestible matter of plant origin (b) supply high quality ("by pass", PDIA or undegradable) proteins. Unlike commercial concentrates, it consists of: (a) farm residues such as haulms and leaves of pulse crops and vegetables, (b) legumes and other fodder trees, (c) byproducts of locally processed food and, to a lesser extent, cash crops such as brans and broken cereals (rice, etc.), cotton seed (lintless) and cakes, palm oil kernels, and (d) by-products of animal origin (fishing, slaughter house) and animal excreta (poultry litter). Work done in China on urea treatment/cotton seed cake supplementation is given as a practical example.

\section{Introduction}

Fibrous feeds or poor quality roughages (PQR) include crop residues and poor quality grasses from rangelands either grazed or, manually collected at a very advanced vegetation stage during the dry season. There constitute without any doubt the basal, and often the sole, components of the ruminants' diets in developing countries with a warm climate.

"Optimizing the use", rather than "improving the nutritive value" of such feeds by ruminants, implies both:

- using treatments, that improve the quality of the roughage per se;

- improving the digestive utilization of these 
feeds, either untreated or treated, through appropriate supplementation and feeding techniques.

This appropriate supplementation may be spontaneously ensured by the grazing animal itself but only when the grazing pressure is light enough to allow selective intake. This is seldom the case with the increasing stocking rates observed in pastoral zones or with the intensification of agro-pastoral zones which calls for reducing the grazing areas in favour of those cultivated.

A tremendous amount of work has been done over the last twenty years at both research and development level on methods and techniques improving the value of fibrous feeds. Many articles, books, leaflets and proceedings have already been produced.

In this paper and in the context of this meeting, we will not carry out a fastidious and probably incomplete enumeration of experimental results and figures.

We will just summarize the basic principles and the main technologies available for optimizing the digestive use of poor quality roughages and discuss the advantages and drawbacks of transferring them in practice.

\section{Optimizing the digestive use of poor quality roughages}

This area has already been reviewed quite clearly in various papers, in particular Leng (1990). We will therefore recall the basic key points related to the digestive utilization of poor quality roughages to be kept in mind when facing a situation involving the use of such feed resources. The aim in fact is to understand the basic principles so that the solution found is adapted to the practical situation in the best possible nutritional way.

Two main steps should be considered :

-feeding the rumen microorganisms in such a way that the growth and activity of the cellulolytic strains are favoured. Because of their poor cell content and high lignified cell walls, fibrous feeds are poorly and slowly digested in the rumen. The energy required for the synthesis and the fermentation activity of the micro organisms is contained in the roughages cell-walls and is slowly released. But PQR are poor in N, minerals and vitamins. The $\mathrm{N}$ requirement for microbial synthesis (roughly estimated at $145 \mathrm{~g}$, crude protein (CP) per kg Organic Matter Fermented, i.e. energy, in the rumen) is not met by the $\mathrm{N}$ intake from the basal diet. $\mathrm{N}$, in the form of degradable proteins (or NPN) for the supply $\mathrm{NH}_{3}$ and aminoacids to the microbes, is therefore the main supplementation component. Minerals such as $\mathrm{S}, \mathrm{P}, \mathrm{Mg}, \mathrm{Cu}$ and $\mathrm{Zn}$ are also vital for the synthesis and activity of the microorganisms;

-feeding the host animal the necessary nutrients (namely amino-acids and glucogenic precursors) ensures a satisfactory nutritional status (including its intake capacity which is generally low with such a type of basal diet) and meets its production requirements. Such supplementation implies feeds that are as rich as possible in by-pass $N$ (proteins of alimentary origin) and in digestible cell walls, so that the cellulolytic type rumen fermentation is endangered as little as possible (to prevent rapid drops of $\mathrm{pH}$ as a result of soluble carbohydrates and starch fermentation);

The utilization of poor quality roughages can be improved either nutritionally by supplementation or technologically, by using treatments. Since the treated roughages have often to be supplemented and since the final objective is to optimize the cellulolysis in both cases of untreated and treated roughages, we will first consider the treatments and, secondly, supplementation.

\section{Treatments}

\section{The various treatments}

The treatments currently available have been described in many review papers and books (including Sundstol and Owen, 1984; Doyle et al, 1986; Schiere and Ibrahim, 1989; Chenost et Kayouli, gone to press). We will therefore summarize by saying that:

-chemical treatments are the most common. They were first based on $\mathrm{NaOH}$ treatments (the "humid" Beckmann's method progressively improved towards less water consuming techniques). But the chemical treatments became attractive to farmers when Sundstol et al (1978) suggested a simple method to inject anhydrous ammonia into stacks of straw on farm scale. Anhydrous ammonia treatment however requires, (a) industrial ammonia, either locally produced or imported, (b) a distribution network: tanks, 
lorries, roads and (c) trained staff for the manipulation of ammonia from the master tank into the stack of straw to be treated. Not all these conditions are regularly met in developing countries. This is why the curea treatment», i.e. "urea-generated ammonia treatment", proved to be an excellent alternative to $\mathrm{NH}_{3}$ treatment, and the best adapted to small production units, both for the individual small scale treatment and for the collective large scale treatment;

-the physical (chopping, grinding, heat/steam treatment, irradiation,...) and the biological methods (culture of white rot fungi and other cellulolytic organisms and direct treatments with cellulases and ligninases) have also to be mentioned. However the physical treatments have been abandoned because of their poor quality/cost ratio in increasing the nutritive value of coarse roughages. Steam treatment is however used in some instances of sugar cane industries where the residual bagass can be improved by the bagass generated steam, bagass being used as fuel. The biological techniques are still too sophisticated to be developed at the practical level. Furthermore the loss of energy in the substrate, subsequent to the development of fungi, is not compensated by the protein-rich substance produced;

-finally an up and coming method is the modification of lignification through genetic engineering. Such an approach has recently given promising results on the tobacco model plant (Bernard Vailhé et al, 1995). Appropriate targeting of the gene regulation would provide plants with improved digestibility and intact physical and agronomical characteristics;

Hence we essentially focus on the urea treatments.

\section{Urea treatment: principles, factors of success and practical implications}

The "urea treatment" is the result of two processes which occur simultaneously within the mass of forage to be treated: ureolysis which turns urea into ammonia, and the subsequently generated effect of the ammonia on the cell walls of the forage. As these processes have already been described and discussed in many review articles we will recall them only briefly in order to concentrate more on their practical implications.

\section{Ureolysis}

-Need for a ureolytic medium:

Ureolysis is an enzymatic reaction that requires the presence of the urease enzyme in the treatment medium. Urease is however practically absent in straw which is a dead graminaceous material.

According to research work (Williams et al, 1984a,b; Yameogo-Bougouma et al, 1993) and much field experience acquired during the last decade, sufficient urease is produced by the telluric ureolytic bacteria during the treatment of residues such as straw or maize stalks, at least under conditions where moisture imposes no limits.

\section{-Moisture content:}

Results of both experimental and practical work carried out up till now show that this percentage should never be less than $30 \%$, and not greater than $60 \%$.

Below $30 \%$, ureolysis can be severely reduced or even not take place. Only in the specific case of intentional water reduction (20 to $25 \mathrm{I}$ added to $100 \mathrm{~kg}$ straw) (Williams et al, 1984a,b; Alibès et al, 1989; Joy et al, 1992 and, for mechanization purposes, Besle et al, 1990) will the addition of urease be necessary. This is generally done through addition of ground raw soya beans in the urea solution.

Below $30 \%$ it would also be more difficult to compress the mass of forage and expel the air when the forage is in loose form (fewer problems are encountered with bales since the plant is already pressed). As a result, a lack of $\mathrm{NH}_{3}$ and an excess of oxygen in a medium with sufficient moisture will lead to a bad alkali treatment and to mould development.

Beyond the (arbitrary) upper limit (50 to $60 \%$ ) the problems encountered will be: (a) inadequate consistency of the forage mass, (b) leaching of the urea solution towards the bottom layers (urea/ammonia overdosage with its associated toxicity risks), (c) insufficient diffusion of the generated $\mathrm{NH}_{3}$ within the forage mass, in view of its hygroscopic characteristic (ammonia would bind to the water instead of the plant cell walls), and (d) development of moulds, because of the moisture and an inadequate ammonia environment (trapped by this excessive water).

Within this recommended range, there are no fixed rules and the amount of water to be 
added will be left to the farmer's judgement according to the prevailing local conditions, e.g., availability and cost of water, air humidity, whether the enclosure is watertight, the type of forage to be treated (its structure and compactability). An amount of $50 \mathrm{~kg}$ water to add is an easy figure to remember and is generally applied at the practical level. When added to $100 \mathrm{~kg}$ of a $90 \% \mathrm{DM}$ straw, it leads to a final moisture content of $40 \%$.

Temperature $\mathrm{x}$ duration:

The optimal temperature of ureolysis should lie between 30 and $60^{\circ} \mathrm{C}$, according to the type of urease. When the temperature increased or decreased by $10^{\circ} \mathrm{C}$ the speed of the reaction doubled or halved, respectively. Within the range of temperature of 20 to $45^{\circ} \mathrm{C}$ the ureolysis can be completed after one week, or even in 24 hours. The temperature is therefore not a concern in tropical climates. However the activity of urease is either severely reduced or even suppressed for temperatures below 5 to $10^{\circ} \mathrm{C}$. One must therefore be very careful in tropical highlands (e.g. Tanzania, Madagascar plateaux,.. ) where nightly frosts can take place during the dry season when it is time to treat the straw.

\section{Alkali effect of the generated ammonia}

The factors ensuring a good alkali effect are of course the same as in the case of $\mathrm{NH}_{3}$ treatment and they have been thoroughly reviewed by Sundstol and Owen (1984). The criteria of humidity, temperature and their interaction, necessary for effective ureolysis, will slightly favour the alkali treatment.

However, duration, type of forage and, above all $\mathrm{NH}_{3}$ (and therefore urea) dosage and their interactions will have to be taken into close consideration.

Urea dose (alkali dose) $x$ type of forage $x$ duration:

The quantity of alkali to be used is the first factor responsible for the efficiency of the alkali treatment. It is unfortunately still a controversial subject:

-the majority of anhydrous ammoniac treatments involve $3 \mathrm{~kg}$ ammonia per $100 \mathrm{~kg}$ DM of treated straw (Sundstol and Owen, 1984). This figure might correspond, if ureolysis is complete, to $5.3 \mathrm{~kg}$ of urea per 100 $\mathrm{kg} \mathrm{DM}$ of straw; many authors, like Williams et al (1984a, 1984b) and Ibrahim and Schiere (1986), have not observed the increase in digestibility of the treated matter that could have been expected with an increased dosage of applied urea. Some even recommend the use, in practice, of threshold dosages of urea of $4 \mathrm{~kg}$ for $100 \mathrm{~kg}$ of straw (rice straw), because higher dosages have not proved that they could improve the treatment;

-the reasons why urea dosages utilised in practice are lower in theory have been discussed elsewhere (Chenost and Besle, 1993). Several phenomena are obviously involved and it is very difficult to dissociate them. We can summarize by saying that:

(a) - at a given $\mathrm{NH}_{3}$ dose, the urea treatment is most probably more efficient and the tendency is to reduce the quantity of urea;

(b) - even if it is more efficient than ammonia treatment, the urea treatment is slower (Sahnoune, 1990). It is therefore possible that some authors, working on treatments of a very short duration, as often happens in tropical areas, did not observe the expected reaction to an increase in urea dosage;

(c) -finally, and above all, the capacity of the forage to react to alkaline treatment depends upon the botanical family, the species and the variety to which it belongs. Little is known, and therefore it is difficult to quantify, in the nature and the structure of the cell walls (lignins) what could possibly explain this capacity to react to alkaline treatment. As a result there would therefore be not one but several optimal dosages of alkali, differing according to the botanical family, species and variety to which the straw or forage belongs. For instance dosages which are sufficient for certain rice straws, might not be for others, and probably less so for wheat straws:

We unfortunately still lack tools to predict these differences. However, the capacity of a straw to respond to alkaline treatment shows relationship to its buffering capacity (phosphate) and to the saponifiable ester linkages (Dias da Silva and Guedes, 1990) or to the optical density at $280 \mathrm{~nm}$ (Besle et al, 1989) of the buffer extract. Colucci et al (1992), in agreement with Tuah et al (1986) and Givens et al (1988), observed that this capacity is all the larger as the initial digestibility of the straw is low, and that the links between initial digestibility and response to treatment are specific to the botanic species.

In such circumstances the decision should 
be taken in a practical situation. The majority of both experimental and field work has concluded that the recommended dose is $5 \mathrm{~kg}$ urea per $100 \mathrm{~kg}$ (as such) of straw. This dose gave good results in many field projects in Africa, Madagascar and Asia (Chenost and Kayouli, gone to press).

Attempts are being made, essentially in China and Vietnam, to reduce the amount of urea without losing alkali treatment efficiency through association of lime $\left(\mathrm{Ca}(\mathrm{OH})_{2}\right)$ with urea. A recent trial in Vietnam (Bui Van Chinh et al, 1994) would seem to indicate that treating with $2.5 \%$ urea plus $0.5 \%$ lime and $0.5 \%$ salt gives the same increase of the rice straw feeding value compared to a $5 \%$ urea treatment.

Duration $x$ ambiant temperature:

The duration of the alkali treatment per se is longer than the ureolysis process. The recommended treatment time ranges from more than 8 weeks for temperatures around $5^{\circ} \mathrm{C}$ to less than 1 week for temperatures above $30^{\circ} \mathrm{C}$ (Sundstol and Owen, 1984).

In classical tropical climates the alkali treatment can thus be achieved after 1 week. However, in view of what has been said earlier, the duration to be recommended in practice should never be below 1 week. As treatment efficiency improves with time it is advisable to wait 2 weeks before opening the stack unless constraints make this impossible. In tropical highlands (e.g. Tanzania, Madagascar plateaux,...) where nightly frosts can take place during the dry season it is better to recommend at least 3 weeks. We were even compelled to advise 5 weeks at the practical level in the case of the Madagascar Merina Highlands (Chenost, 1993) in view of the very cold nights (periodical slowing down of the ureolytic activity from day to night time) that occur during winter dry season.

Air and watertightness:

Ammonia is released much more slowly from the ureolysis process than from an anhydrous ammonia tank injection. The risks of losses of ammonia into the atmosphere is thus reduced since ammonia can bind on the forage cell walls and on the water medium almost simultaneously to its release. However only around $1 / 3$ of the $\mathrm{NH}_{3}$ released can bind the plant material, the remaining $2 / 3$ being in a labile form is lost.
This point will be all the more important as the storage duration is long and the volume of material treated is small. Indeed the aim is to maintain an atmosphere as anaerobic and ammoniacal as possible within the mass of forage in order to achieve not only the best treatment but also the smallest development of moulds possible.

\section{Other "urea» treatments}

A rather old but not yet widespread procedure is to utilize urine as the source of urea. The first trials took place in Sri Lanka and Bangladesh in the early $80 \mathrm{~s}$. Dias da Silva's review (1993) on this subject concluded that,

- the treatment efficiency depends largely on the urine variability itself (urea dilution, type of animals or, of the dietary regimen);

- because of the more importantly urine/straw ratio necessary to get an increase in digestibility values, the acceptability of the treated material is somewhat reduced;

- the urine collection, storage and handling still remain a constraint at the practical level;

There is further work to be done on this kind of treatment.

\section{Practical aspects of urea treatment}

Various types of treatments have been described in many review papers, books (including Schiere and Ibrahim, 1989 and, more recently, Chenost and Kayouli, gone to press), and in technical leaflets. There is not a single fixed model technique but reasoned techniques which must each adapt to the prevailing agro-economical conditions which are,

- the straw or forage conditioning: loose form, either long or chopped; bales, either manually or mechanically (pressed) made;

- the quantity of forage or straw to be treated, depending on the number of animals and the time during which they have to be fed;

- the farmer's technical skill and facilities and his budget;

Once treated and if sufficiently well covered to be maintained in anaerobic conditions, the forage can be stored for several months. It is therefore in a single operation possible theoretically to treat the quantities required for the whole feeding period. These quantities may however be sometimes too large and require too much labour and storage 
space. It is then necessary to treat smaller quantities in successive operations repeated during the period of feeding. Various types of treatment are possible depending on the strategy chosen (optimum compromise between frequency and size).

They range from the small pit dug in the soil (only in firm clay and not draining soils) to the classical pressed bales stack covered with plastic sheets, as in the anhydrous ammonia treatment with all the intermediary solutions such as baskets or any other mobile containers, various types of clamps ( 3 wallssystem), existing constructions e.g. storehouses, unused pens.

The main subject of controversy, after urea dose and moisture percentage dealt with earlier, is the air and watertightness of the treatment medium. Quite often now it is said that the urea treatment does not require any covering: such advice is dangerous and ambiguous. When the treated roughage must be stored for a long time, it is necessary to cover it in order to avoid mould development and poor ammonia fixation.

However practical field observations in tropical Asia, which were also confirmed experimentally in Spain by Joy et al (1992) showed that in the case of large stacks, it is possible to "cover" them with untreated sheaves or bales of straw that provide a "self cover". The outer straw, which is of course somewhat damaged, represents only a small proportion in comparison with the whole bulk of satisfactorily treated. This possibility does not apply in the case of small quantities to be treated where covering remains necessary.

In these latter cases however the use of local material can solve the problem without resorting to the conventional plastic sheets. Successes have been observed using banana leaves or sheaths, seko mats, banco, mud or old plastic bags sewn together. In Tunisia and Morocco, where mud has been used for decades by farmers to protect their stacks of straw against rain. It has recently been shown (Ben Salem et al, in press) that mud is a successful alternative to plastic for covering large urea-treated stacks.

\section{Assessment of treatment efficiency}

The best assessment of treatment efficiency is of course the animal's response in terms of intake and performances. However, in field conditions, the question is often raised by the extension agents on opening the silo, pit, clamp or stack they prepared with the farmers how can they be sure, that their treatment has been successful prior to feed it to the animals.

Without going again into the detail controversy linked with the prediction aspects of the feeding value of treated (and moreover untreated) straws and poor quality roughages, we can summarize by saying that :

- the first and simplest criterion of a successful treatment is the physical aspect of the treated roughage : (a) marked change of colour from clear yellow to brown or dark brown (dark yellow is not enough), (b) strong but good ammonia smell without any trace of bad fermentation, (c) smooth texture of the straw or the stalks which become easy to twist and to bend, (d) absence of any mould;

- if doubt persists, the Kjeldalh $\mathrm{N}$ assay can be used. In the case of anhydrous $\mathrm{NH}_{3}$, a poor alkali treatment is generally associated with a poor $\mathrm{N}$ fixation and therefore a low $\mathrm{CP}$ content. The increment of the CP content of DM should at least be of 5-6 percent (CP/DM from 3-4 up to $9-10 \%$ ), taking into account the systematic $2 / 3$ loss in the form of labile ammonia that cannot bind. In the case of urea treatment one important point, which is generally misinterpreted, is that, when the assay is done on the dry sample as above, a greater increment is not necessarily synonymous with a successful treatment. On the contrary, it should warn that residual urea has not been totally converted into $\mathrm{NH}_{3}$ because of partial ureolysis (and, therefore, only a little ammonia has been produced). As a matter of fact a $4 \%$ CP straw "treated» with $5 \mathrm{~kg}$ urea / $100 \mathrm{~kg}$ ends up with a CP content of $18.6 \%$ when no ureolysis has taken place. When the assay is done on a fresh and non aerated sample the $\mathrm{CP}$ content may be high too, not only reflecting non hydrolysed urea, but also labile $\mathrm{NH}_{3}$ absorbed but not bound to the plant;

- the third step, which is only justified when dealing with relatively high producing animals that must not be underfed, is to use the prediction of digestibility/intake in view of the need for more precision;

(a) - the classical proximate feed analysis can in no way predict any feeding value. As CF (crude fibre), NDF (neutral detergent fibre), ADF (acid detergent fibre) and $A D L$ (acid detergent lignin) are of no use, they are not recommended.

(b) - The only options available are the in 
sacco technique or gas test for degradability measurement, or cellulase or in vitro digestibility techniques for digestibility prediction which are however expensive.

All these points have already been widely discussed in the literature (summarized in Chenost and Reiniger, 1989) but it was worth mentioning them in the particular case of poor quality roughages.

\section{Response to treatment}

Compilations, including Chenost and Kayouli (gone to press), from both on station and on farm trials in various parts of the world, in particular Asia and Mediterranean countries, state that, when properly achieved and utilized, urea treatments can increase:

-the CP content by an average of 6 to 7 percent $(S E=3.0$ ). However, a point of interest, mentioned by several authors, but quite often forgotten is the relatively bad utilization by the animal of the $\mathrm{N}$ provided by the treatment (Demarquilly et al, 1989), which is reflected by the high $\mathrm{N}$ faecal excretion. As a result, farmers indeed observe a better agronomical value of the manure collected from the animals fed with treated roughages (Kayouli, 1994a, 1994b);

-the OM digestibility by an average of 10 to 15 percent. The improvement of digestibility is all the more important as the initial digestibility is low. The latter point highlights the need for further research into prediction criteria of PQR digestibility that would enable to distinguish the better ones prior the decision to treat;

-the roughage intake (Table I) by about $40 \%$ subject to much variation, depending essentially upon the way the treated roughage is fed (proportion and nature of the supplement in the diet) and the type of animals;

With regard to the animal performances:

-the treatment improves the nutritional status of animals and their performances;

-at the same appropriate level of supplementation, treated roughages compared to untreated roughages ensure average improvements of $200 \mathrm{~g} / \mathrm{d}$ of the ADG (average daily gain) for growing cattle (Table I), and increase by 1.0 to $2.5 \mathrm{~kg}$ milk collected per day above the amount suckled by the calf. Table II illustrates the benefit that the couple

Table I. Effect of urea treatement ( 4 to $6 \mathrm{~kg} / 100 \mathrm{~kg}$ straw) of rice straw on straw intake and average daily gains with young cattle and buffaloe (same level of supplementation untreated / treated)(South East Asia).

\begin{tabular}{|c|c|c|c|c|c|c|c|c|}
\hline \multirow{2}{*}{$\begin{array}{l}\text { Animals } \\
\text { ( Liveweight, kg) }\end{array}$} & \multirow{2}{*}{$\begin{array}{r}\text { Urea } \\
(\mathrm{kg} / 100 \mathrm{~kg} \\
\text { straw) }\end{array}$} & \multicolumn{3}{|c|}{ Straw intake (kg DM/d) } & \multicolumn{3}{|c|}{ Average daily gain $(\mathrm{g} / \mathrm{d})$} & \multirow[b]{2}{*}{ References } \\
\hline & & $\begin{array}{c}\text { Un- } \\
\text { treated }\end{array}$ & Treated & increase & $\begin{array}{l}\text { Un- } \\
\text { treated }\end{array}$ & Treated & increase & \\
\hline Buffaloe $(200)$ & 5 & 4.21 & $4 . \overline{75}$ & 0.54 & -182 & 79 & 261 & Wanapat et al, 1984 \\
\hline \multirow[t]{2}{*}{ Buffaloe (290) } & 3 & 5.87 & 6.42 & 0.55 & -130 & -50 & 180 & Wongsrikeao and \\
\hline & 6 & 5.87 & 7.32 & 1.45 & -130 & 210 & 340 & Wanapat et al, 1985 \\
\hline Cattle $(60)$ & 5 & 1.70 & 1.90 & 0.20 & 35 & 110 & 75 & Saadullah et al, 1982 \\
\hline Cattle (130) & 5 & 2.93 & 3.68 & 0.75 & 125 & 310 & 185 & Khan et al, 1982 \\
\hline Cattle (170) & 4 & 2.09 & 2.84 & 0.75 & 73 & 346 & 273 & Perdok et al, 1982 \\
\hline \multirow[t]{2}{*}{ Cattle (120) } & & 3.40 & 3.30 & -0.10 & 224 & 306 & 82 & Saadullah et al, 1982 \\
\hline & & 3.30 & 3.40 & 0.10 & 193 & 295 & 102 & \\
\hline Cattle (285) & 5 & 4.97 & 6.82 & 1.85 & -134 & 430 & 564 & Wanapat et al, 1982 \\
\hline & 5 & 2.69 & 4.82 & 2.13 & -312 & 75 & 387 & \\
\hline Cattle (65) & 5 & 2.00 & 2.20 & 0.20 & 107 & 295 & 188 & \multirow{3}{*}{$\begin{array}{l}\text { Hamid et al, } 1983 \\
\text { Haque and Saadullah, } \\
1983\end{array}$} \\
\hline Cattle (125) & 5 & 2.40 & 4.80 & 2.40 & 114 & 227 & 113 & \\
\hline \multirow{3}{*}{ Cattle (165) } & 5 & 2.40 & 4.60 & 2.20 & 132 & 227 & 95 & \\
\hline & 4 & 3.39 & 4.19 & 0.80 & 141 & 308 & 167 & \multirow{2}{*}{$\begin{array}{l}\text { Kumarasuntharam } \\
\text { et al, } 1984\end{array}$} \\
\hline & $\begin{array}{l}4 \\
4\end{array}$ & $\begin{array}{l}3.39 \\
3.39\end{array}$ & $\begin{array}{l}4.75 \\
3.94\end{array}$ & $\begin{array}{l}1.36 \\
0.55\end{array}$ & $\begin{array}{l}141 \\
141\end{array}$ & $\begin{array}{l}207 \\
336\end{array}$ & $\begin{array}{r}66 \\
195\end{array}$ & \\
\hline Cattle (-) & 4 & 2.00 & 3.00 & 0.90 & 103 & 282 & 179 & Perdok et al, 1984 \\
\hline average & & 3.29 & 4.28 & 0.98 & 38 & 235 & 203 & 11 references, 17 trials \\
\hline SE & & - & - & 0.76 & & & 127 & - \\
\hline
\end{tabular}


cow/suckling calf can receive from treatment in terms of body weight gain.

-a better working efficiency of drought animals as well as their body conditions after the working season are systematically observed (quantification being too difficult) in practical field conditions;

As shown in Table III, due to the alkali effect on cell wall digestibility, a given amount of urea leads to a better response with the treatment than by supplementation used on its own.

One important feature to bear in mind is that the lower the production level of animals, the better the response to feeding with treated $P Q R$. Treated PQR are all the more optimized as their proportion in the diet increases.

\section{Conclusion on urea treatments}

It is now possible to say that, provided some key rules are observed, the "urea treatment" is technically perfectly adapted to the small production units, at both the individual and the cooperative level. Much practical field experience has been acquired now in an extremely wide range of agro-ecological and sociological conditions.

Sealing is less a concern than with an anhydrous ammonia treatment and is not necessarily important when large quantities of plant material are treated (self covering).

Animal response to urea treatment is similar to the anhydrous ammonia treatment achieved at the same alkali level. This response is optimum with mean yielding animals making them the «target animals».

The actual rate of adoption in practice remains to be analysed further.

\section{Supplementation of untreated and treated poor quality roughages (PQR)}

\section{Principles}

An appropriate supplementation to PQR should first favour the rumen cellulolysis, then enhance rumen microbial synthesis and supply the animal with the required nutrients for maintenance and, when necessary, for production, bearing in mind that these nutrients cannot be compared with those expected with good forages.

\section{The catalytic supplementation for subsistence or modest production}

The first step in supplementation is the "catalytic" step which ensures a good cellulolytic rumen ecosystem by supplying NPN (namely urea) and minerals. Such supplementation hardly covers the maintenance requirements of the animals.

The strategical supplements are urea and minerals. There are two main ways of giving them to the animal.

The older way is to use liquid molasses as their carrying medium. Molasses-urea mixtures are still being used and commercialized in some countries, for instance:

- In Egypt, where the molasses-urea feed (Mufeed) is commercialized and transported by tanks. The table IV provides the formula of that mixture as an example:

- Or in Tanzania, where the molasses-urea mixture (MUM) is distributed through the village cooperatives. In this case MUM contains 3\% urea and minerals. It is distributed at the rate of $0.5 \mathrm{~kg} /$ day $/ 100 \mathrm{~kg}$ liveweight to Tanzanian Zebu Shorthorn cows (250 to $300 \mathrm{~kg} \mathrm{LW}$ ) producing 5 to $6 \mathrm{~kg}$ milk / day on top of the milk suckled by the calf. It is sprayed on the zero fed roughage (banana leaves, along side roads cut grasses, and maize stovers in dry season). According to farm records average increase in milk production of $0.5 \mathrm{~kg}$ per $\mathrm{kg}$ MUM fed is shown (Laurent and Centres, 1990).

A more convenient practice, developed by the FAO, that is becoming popular throughout developing countries, is the multinutritional block (Sansoucy, 1986 and 1995). The carrying medium is solid and therefore easier to transport. The block is licked by the animal, which ensures a small progressive and regular intake of urea. Molasses can even be substituted for other ingredients e.g. lime, clay and/or cement.

These blocks provide the opportunity of utilizing any type of locally available agroindustrial by-products e.g. brans, pulps, poultry litter (Kayouli et al, 1993), which provide the animal with other nutrient sources than urea and mineral which are fundamental. Examples of block composition developed in various countries are given in Table $\mathrm{V}$.

Average daily intake is 400 to $800 \mathrm{~g}$ for large ruminants, 300 to $500 \mathrm{~g}$ for camels and 100 to $250 \mathrm{~g}$ for small ruminants. With a urea 
Table II. Effect of treating rice straw on the cow/calf performances (Bangladesh).

\section{$\overline{\text { Rice straw (ad libitum ) }}$ \\ $\overline{\mathrm{Nb}}$ of animals \\ Dry matter intake $(\mathrm{kg} / \mathrm{d})$ \\ straw \\ concentrate}

Milk produced (kg/day, over calf)

Average daily gain $(g / d)$

$$
\text { cow }
$$

calf

(Perdok et al, 1982)

\section{Untreated}

17

5.20

1.50

2.42

$-266$

181
Treated

17

8.60

1.50

3.41

93

Table III. Comparison of the effect of the same quantity of urea, used either as supplement or for treating rice straw on intake and growth rate of cattle (South East Asia).

\begin{tabular}{|c|c|c|c|c|c|c|c|}
\hline STRAW & NT & $\mathrm{CU}$ & TU & NT & $\mathrm{CU}$ & TU & - \\
\hline $\begin{array}{l}\text { Animals } \\
\mathrm{LW}(\mathrm{kg})\end{array}$ & & W int & & & $\begin{array}{l}\text { veight } \\
(g / d)\end{array}$ & gain & References \\
\hline Cattle (130-140) & 1.7 & 1.7 & 1.9 & 35 & 75 & 110 & Saadullah et al, 1981 et 1982 \\
\hline Cattle & 2.1 & 2.3 & $2,9-3,0$ & 103 & 213 & $237-310$ & Perdok et al, 1984 \\
\hline Cattle (75-78) & & 2.2 & 2.4 & & 207 & 297 & Saadullah et al, 1983 \\
\hline Cattle (166-178) & 3.4 & & $3,9-4,8$ & 141 & & $207-336$ & Kumarasuntharam et al, 1984 \\
\hline Cattle & & 2.8 & $4.0^{\circ}$ & & 111 & 246 & Jaiswal et al, 1983 \\
\hline Cattle (177-196) & 4.3 & & 3.6 & 304 & & 598 & Promma et al, 1985 \\
\hline
\end{tabular}

Straw : NT - untreated; CU - supplemented with urea; TU - urea treated

after Chenost and Kayouli, in press.

Table IV. Molasses-urea mixture utilized in Egypt (Barker et al, 1987).

$\begin{array}{lr} & p .100 \\ \text { molasses } & 91,36 \\ \text { urea } & 2,50 \\ \text { mineral mixture } & 1,14 \\ \text { water } & 5,00\end{array}$

The mineral mixture contains 14.6 p. $100 \mathrm{P} ; 5.0$ p. $100 \mathrm{Mg} ; 6.6$ p.100 S; vitamin A, $230000 \mathrm{IU} / \mathrm{kg} ;$ vitamin D, $46000 \mathrm{lU} / \mathrm{kg}$; vitamine E, $1270 \mathrm{ppm} ; \mathrm{Fe}, 3700 \mathrm{ppm} ; \mathrm{Zn}, 3000 \mathrm{ppm}$; Mn, $2500 \mathrm{ppm} ; \mathrm{Cu}, 630 \mathrm{ppm} ; \mathrm{Co}, 60 \mathrm{ppm}$; $1200 \mathrm{ppm}$. 
incorporation rate of 5 to $10 \%$, these intakes allow a $\mathrm{N}$ ingestion that covers the $\mathrm{N}$ microbial requirement absolutely necessary for the fermentation of the potentially degradable Organic Matter contained in the straw or roughage fed or grazed. As this degradation is accelerated the actual intake of roughages is improved. As a result of expressing the potential digestibility of the roughage and improving its intake, the physiological status of the animal, its liveweight gain, working efficiency or milk production, are improved in a substantial way (Table VI and Wanapat et al, 1991).

Such blocks can be manually manufactured at the village or cooperative level or by the small farmer himself with minimal investment.

\section{Supplementation for a higher production level (untreated and treated PQR)}

The second step in supplementation concerns the ehost animal", where the catalytic supplementation becomes inadequate to sustain some more production than the maintenance.

This supplementation should,

(a) be as "cellulolytic» (digestible cell walls) as possible to avoid any negative digestive interactions and too high a substitution of the roughage for the supplement,

(b) be given in such amount that the major part of the diet is constituted by the basal PQR (2/3 when supplementation is rich in starch, 1/2 when supplementation is rich in digestible cell walls).

(c) bring a maximum amount of digestible nutrients to the intestine (without having gone through ruminal fermentation ) to satisfy the animal's productive needs, so that there is a synergical effect on PRQ utilization.

Points (a) and (b) are of particular importance in the case of treated PQR if one does not want to lose the benefit of the treatment lost because of negative digestive interactions.

For socio-economical reasons supplementation should be ensured by as much local feed resources as possible and avoid the use of classical concentrates (or their components, earmarked for human and non ruminant nutrition, i.e. cereals and high quality oil cakes, which are unfortunately quite often exported).
Contrary to conventional supplements, the main "strategical" supplements, consist of,

- Farm residues such as haulms and leaves of pulse crops and vegetables, these provide green or digestible matter of plant origin (and of course vitamins) and their $\mathrm{N}$ concentration is high,

- By-products of locally processed food and, to a lesser extent, cash crops (which are processed in cities and whose co-products seldom come back to the farmer's village). These are essentially brans and broken cereals (rice,...), cotton seed (lintless) and cakes, palm oil kernels, and provide both energy and proteins of relatively low degradability,

- Tree (mainly legumes) foliages,

these provide digestible cell walls and, more importantly, naturally protected by-pass nitrogen (due to the presence of tannins). This tannin content should not be too high (counteracting proteolysis). Attention should also be paid to the possible presence of other antinutritional factors, their use and interest for animal performance have been highlighted by, inter alia, Doyle et al (1986), Speedy and Plugliese (1992) and Wanapat, (1994) ;

- by-products of animal origin (fishing. slaughter house),

which supply high quality ("by pass" PDIA or undegradable) proteins.

The quantity and nature of the energy supplying fraction of the supplement aside, the quality and the quantity of the supplementary protein have generally tended to be overlooked, particularly in the case of treated roughages. Research and now experimental and practical work clearly show the interest of protein supplementation of treated PQR.

This is illustrated by two examples, one with fish meal, in Table VII and one with cotton seed cake, in Table VIII.

Table VIII summarizes the field work carried out during the last 5 years in two provinces of central China. It shows the interesting responses of intake, digestibility and growth-rate of growing/fattening Yellow Cattle to increasing levels of supplementary cottonseed cake which represents the only supplement of treated roughage since it provides of course energy along with proteins. The zootechnical optimum is obtained with 2 to $3 \mathrm{~kg}$ cotton seed cake/animal/day. Moreover Finlayson's economic study (1993) of fattening operation in China shows that this quantity 
Table V. Examples of mutinutritionnal blocks developed at the farm level (composition in \%).

\begin{tabular}{|c|c|c|c|c|c|c|c|c|}
\hline \multirow{3}{*}{$\begin{array}{l}\text { Countries } \\
\overline{\text { Wheat bran }}\end{array}$} & \multirow[t]{2}{*}{ Senegal } & \multirow[t]{3}{*}{ Niger } & \multirow{2}{*}{\multicolumn{2}{|c|}{$\begin{array}{c}\text { Tunisia, Syria, } \\
\text { Jordan }\end{array}$}} & \multicolumn{4}{|c|}{ Cambodia, Lao,Vietnam } \\
\hline & & & & & & & & \\
\hline & 25 & & 27 & 25 & & & & \\
\hline Other brans (sorghum, ...) & & 65 & & & & & & \\
\hline Rice bran & & & & & 35 & 40 & 40 & 45 \\
\hline Molasses & 50 & 0 & 10 & 0 & 20 & 10 & 5 & 0 \\
\hline Urea & 10 & 10 & 8 & 8 & 8 & 10 & 10 & 10 \\
\hline Salt & 5 & 10 & 5 & 10 & 8 & 5 & 5 & 5 \\
\hline Lime & 5 & & 5 & 0 & 5 & 5 & 5 & 5 \\
\hline Cement & 5 & 15 & 10 & 15 & 5 & 5 & 10 & 10 \\
\hline Bicalcic phosphate & & & 5 & 0 & & & & \\
\hline Poultry litter & & & 15 & 20 & & & & \\
\hline Olive cake & & & 15 & 22 & & & & \\
\hline Bone meal & & & & & 0 & 5 & 5 & 5 \\
\hline Clay & & & & & 20 & 20 & 20 & 20 \\
\hline Total & 100 & 100 & 100 & 100 & 100 & 100 & 100 & 100 \\
\hline Water (I) & & $40-50$ & $10-20$ & $30-35$ & $10-15$ & $20-25$ & $20-25$ & $25-30$ \\
\hline
\end{tabular}

Table VI. Effect of supplementation with multinutritional blocks on intake and animal performances.

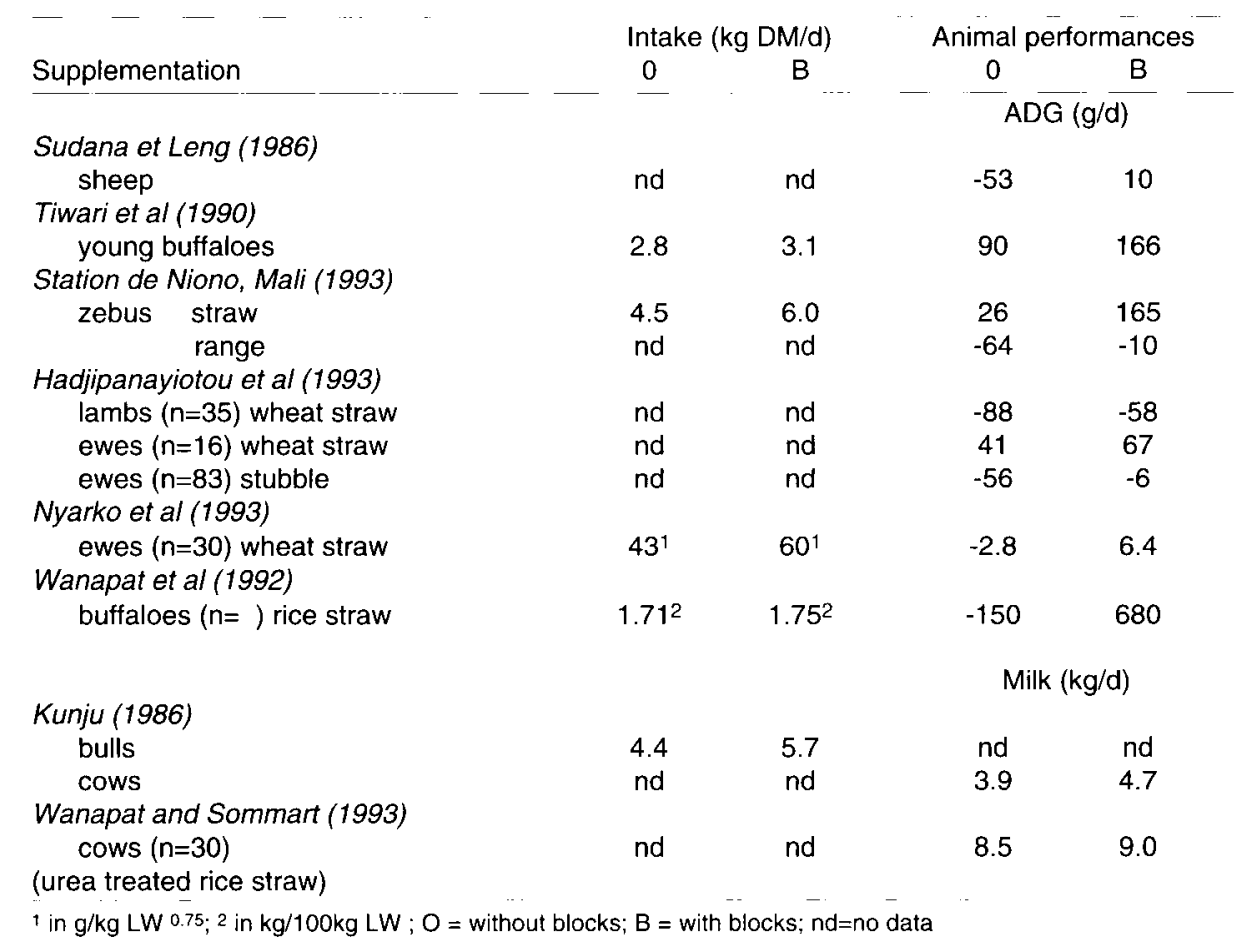


Table VII. Effect of fish meal supplementation on the digestibility of a urea treated rice straw and on animal performances (cattle) in Bangladesh (Saadullah et al, 1982).

$\begin{array}{lccccc}\text { Ration } & 1 & 2 & 3 & -1 \\ \text { Fish meal }(\mathrm{kg} / \mathrm{d}) & 0.0 & 0.1 & & 0.2 & 0.3 \\ \text { Treated rice straw }(\mathrm{kg} / \mathrm{d}) & 2.6 & 2.3 & & 2.3 & 2.4 \\ \text { Water hyacinth }(\mathrm{kg} / \mathrm{d}) & 0.2 & 0.1 & & 0.1 & 0.1 \\ \text { DM Digestibility }(\%) & 50 & 57 & 60 & 62 \\ \text { Average daily gain }(\mathrm{g} / \mathrm{d}) & 57 & 198 & & 205 & -192\end{array}$

Table VIII. Response of chinese " Yellow Cattle « intake and growth rate to increasing levels of cotton seed cake as supplements of urea treated rice straw (after Fan et al, 1993 (1) and Zhang Wei Xian et al, 1993 (2))(duration 90 days).

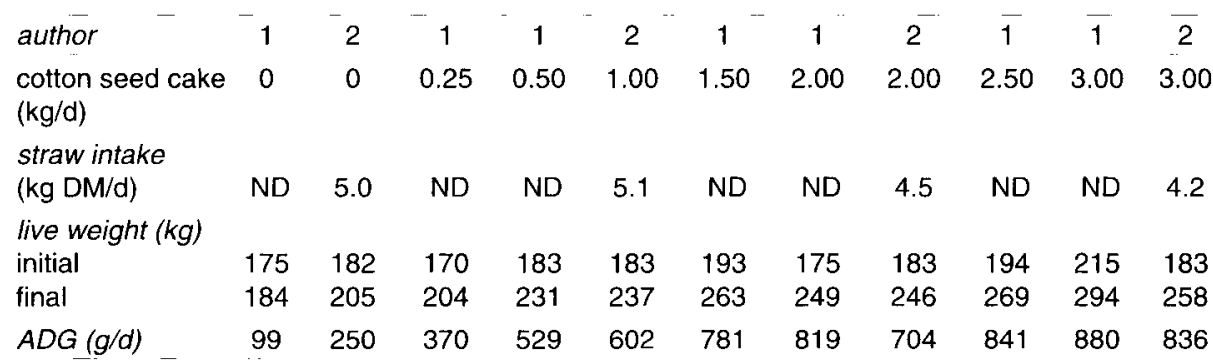

does not represent the economical optimum. This is $1 \mathrm{~kg} / \mathrm{head} /$ day when considering the maximum profit per animal fattened and 2 $\mathrm{kg} / \mathrm{head} /$ day when considering the maximum profit per fattening day.

This "synergical» supplementation, unfortunately does not in practice always respect the above considerations. In systems where cereals may be at certain times of the year cheaper than straw (the Maghreb, Near East,...) the synergic properties of local resources are neglected in favour of commercial concentrates which are over proportionally used.

When lower animal performance levels are admissible treatment without supplementation should be enough. However it is very important to make sure that minerals are adequatly supplied so that the effectiveness of the treatment is maintained.

\section{Conclusion}

Urea treatment and multinutritional blocks represent the simplest and easiest way for optimizing PQR in ruminants. They are now widely used in practice (the Maghreb and Near East, Niger, South East Asia and China), or their use is coming into effect (Madagascar, Mali, Mauritania, Tanzania, Togo), to quote some examples where governments have officially been involved.

Recommendations given relative to urea treatment should not be followed rigidly but, to the contrary, should be reasoned and adapted to the agro-ecologic conditions in which the treatment is carried out.

Improved knowledge of the capacity of straws to respond to alkaline treatment should allow the modulation of the urea dosages to be used to improve the efficiency of the treatment. This capacity unfortunately remains difficult to predict because there are no simple or reliable criteria.

More attention should be paid to the use of locally available feed resources as "synergical» supplementation of PQR, either treated or untreated. For instance, the relatively poor quality of the nitrogen generated 
via treatment justifies the importance of correct reasoning of the quantity and, above all, the nature of the nitrogen complement in treated forages.

Development measures, to be followed along with the extension programmes of such techniques, and agro-economical and sociological considerations regarding rate of adoption and impact of such techniques, deserve the utmost attention when launching poor quality roughages-based development programmes based on poor quality roughages.

\section{Literature cited}

Alibes X, Munoz F, Joy M (1989) Effects of moisture level, temperature and soya bean addition on the nutritive value of urea treated maize stover and wheat straw. In: Workshop "Cellulose" (OECD), INRA, Nantes, France

Barker IJ, Yacout $H$, Creek MJ, Hathout $M, E l$ Nouby $H$ (1987) Transfert des systèmes d'affouragement de la phase expérimentale à l'éleveur. Egypte - Alimentation bovine, Rev Mond de Zootech 6, 17-25

Bernard Vailhe MA, Besle JM, Cornu A, Maillot MP (1995) Composition and biological degradability of lignin modified transgenic plants. Ann Zootech 44, 68

Besle JM, Signoret $\mathrm{C}$, Chenost M, Aufrère J, Jamot J (1989) Prediction of ammoniated and untreated straw organic matter digestibility by densitometry. Comparison with other predictors. In: Evaluation of straw in ruminant feeding ( $\mathrm{M}$ Chenost, $\mathrm{P}$ Reiniger, eds) Elsevier, London, New-York, 134-143

Besle JM, Chenost M, Tisserand JL, Lemoine JP, Faurie F, Saleh H, Grenet N (1990) Ammoniation of straw by urea: extent of ureolysis and improvement of nutritive value with moderate water addition. Reprod Nutr Dev suppl 2, $174 \mathrm{p}$

Bui Van Chinh, Le Viet Ly, Nguyen Huu Tao, Pham Van Thin NH (1994) Ammoniated rice straw or untreated straw supplemented with a molassesurea block for growing cattle in Vietnam. In: Proc Nat Workshop on Sustainable livestock production on local feed resources, Publish House, Univ of Agric and Forest, Ho Chi Minh City, Vietnam, 67-70

Chenost M, Besle JM (1993) Ammonia treatment of crop residues via ureolysis: some reflection on the success of the treatment and on the utilization of the treated material. In: Proc Inter Conf on Increasing livestock production through utilization of farm and local resources, Beijing, China, 153-171

Chenost M, Reiniger P (1989) (eds) Evaluation of straws in ruminant feeding. Elsevier Science Publishers LTD, $182 \mathrm{p}$

Colucci PE, Falk D, Mc Leod GK, Grieve DG (1992) In situ organic matter digestibility of untreated and urea-treated varieties of spring barley and oat straws and of untreated varieties fo winter wheat straws. Anim Feed Sci Technol 37, 73-84

Demarquilly C, Chenost M, Ramihone B (1989) Intérêt zootechnique du traitement des pailles à l'ammoniac. In: Pâturages et alimentation des ruminants en zone tropicale humide (Xandé $\mathrm{A}$, Alexandre G, eds) INRA, Paris, 441-455

Dias da Silva AA (1993) Upgrading of low quality feeds by means of urinary urea. In: Urine-a wasted, renewable natural resource ( $F$ Sundstol, E Owen, eds) Proc Workshop Agric Univ Norway, Development and Environment, 12, NORAGRIC Occasional Papers Series C, 43-49

Dias da Silva AA, Guedes CVM (1990) Variability in the nutritive value of straw cultivars of wheat, rye and triticale and response to urea treatment. Anim Feed Sci Technol 28, 79-89

Doyle PT, Devendra C, Pearce GR (1986) (eds) Rice straw as a feed for ruminants. IDP, Canberra, Australia, $117 \mathrm{p}$

Fan JW, Gu CX, Tian JZ, Dolberg F, Finlayson PM (1993) Effect of ammonia treatment and level of cottonseed cake on performance, digestibility and intake of chinese yellow cattle. In: Proc eedings of the International Conference on Increasing Livest Prod through Utilization of Local Resources, Beijing, 18-22 october, 271281

Finlayson PM (1993) Economic aspects of utilizing fibrous crop residues for beef production in China. In: Proc Int Conf Increasing livestock production through utilization of local resources. Beijing, 485-493

Givens DI, Adamson AH, Cobby JM (1988) The effect of ammoniation on the nutritive value of wheat, barley and oat straws. Digestibility and energy value measurements in vivo and their prediction from laboratory measurement. Anim Feed Sci Technol 19, 173-184

Hadjipanayiotou $M$, Verhaeghe $L$, Labban $L M$, Shurbaji A, Kronfoleh AER, Al-Wadi M, Amin M, Naigm T, El-Said H, Alharess AK (1993) Feeding ensiled poultry excreta to ruminant animals in Syria. Livestock Res Rural Dev 5, 30-38

Hamid MA, Haque M, Saadullah M (1983) Water hyacinth as a supplement for ammoniated rice straw. In: Maximum livestock production from minimum land $(\mathrm{CH}$ Davis, TR Preston, $\mathrm{M}$ Haque, M Saadullah, eds) Depart Anim Sci, Bangl Agric Univ, Mymensingh, Bangladesh, $32 \mathrm{p}$

Haque M, Saadullah M (1983) Liveweight gains and gut contents of calves fed ammonia (urea)treated or untreated rice straw with or without 
water hyacinth. In: Maximum livestock production from minimum land $(\mathrm{CH}$ Davis, TR Preston, $\mathrm{M}$ Haque, M Saadullah, eds), Depart Anim Sci, Bangl Agric Univ, Mymensingh, Bangladesh, 45-46

Ibrahim MNM, Schiere JB (1986) Extension aspects of treatment application at farm level. In: Rice straw and related feeds in ruminants rations, (MNM Ibrahim, JB Schiere, eds) Proc inter workshop, Straw utilization project, Kandi, Sri Lanka, 201-207

Jaiswal RS, Verma ML, Agrawal is (1983) Effect of urea and protein supplement added to untreated and ammonia-treated rice straw on digestibility, intake and growth on crossbred heifers. In Maximum livestock production from minimum land $(\mathrm{CH}$ Davis, TR Preston, $M$ Haque, $M$ Saadullah, eds) Depart Anim Sci, Bangl Agric Univ, Mymensingh, Bangladesh, 26-31

Joy M, Alibes X, Munoz F (1992) Chemical treatment of lignocellulosic residues with urea. Anim Feed Sci Technol 38, 319-333

Kayouli C, Demeyer DI, Accacha M (1993) Evaluation of poultry litter and olive cakes as alternative feed for ruminant production in Tunisia. In: Proc Inter Conf on Increasing livestock production through utilization of local resources, Beijing, China, 420-440

Khan AKM, Nurazzamal, Davis CH (1982) Effect of the level of feeding urea-treated paddy straw on the performances of growing cattle. In: Maximum livestock production from minimum land (Davis $\mathrm{CH}$, Preston TR, Haque $\mathrm{M}$, Saadullah $\mathrm{M}$, eds) Depart Anim Sci, Bangl Agric Univ, Mymensingh, Bangladesh, 143-145

Kumarasuntharam VR, Jayasuriya MCN, Joubert $M$, Perdock HB (1984) The effect of method of ureaammonia treatment on the subsequent utilization of rice straw by draught cattle. $I n$ : The utilization of fibrous agricultural residues as animal feeds (Doyle PT, ed) School of Agric and Forest, Univ of Melbourne, Parkville, Victoria, 124-130

Kunju PJG (1986) Urea molasses block: A futur animal feed supplement. Asian Livestock, II, FAO Regional Office, Bangkok, Thailand, 153-159

Laurent C, Centres JM (1990) Elevage bovin laitier en Tanzanie. Un programme de développement pour les petits producteurs des régions Kilimandjaro et Arusha. (Doc travail URSAD, Versailles, Dijon, Mirecourt), INRA $110 p$

Leng RA (1990) Factors affecting the utilization of poor quality forages by ruminants particularly under tropical conditions. Nutr Res reviews 3 , 277-303

Nyarko-Badahu DK, Kayouli C, Ba AA, Gasmi A (1993) Valorization of cereal straws in the feeding in the North of Tunisia. In: Proc int Conf increasing livestock production through utilization of local resources Beijing, 172-184

Perdok HB, Thamotharam M, Blom JJ, Van Den Born
$H$, Van Veluw C (1982) : Practical experiences with urea ensiled straw in Sri Lanka. In: Maximum livestock production from minimum land (CH Davis, TR Preston, $M$ Haque, $M$ Saadullah, eds) Depart Anim Sci, Bangl Agric Univ, Mymensingh, Bangladesh, 123-134

Perdok HB, Muttettuwegama GS, Kaasslhieter GA, Boon HM, Van Wageningen MM, Arumugam $V$, Linders MGFA, Jayasuriya MCN (1984) Production responses of lactating or growing ruminants fed urea-ammonia treated paddy straw with or without supplements. In: The utilization of fibrous agricultural residues as animal feeds (PT Doyle, ed) School of Agric and Forest, Univ of Melbourne, Parkville, Victoria, 213-230

Promma S, Tuikumpee S, Ratnavanija A, Vidhyakorn $N$. Froemert R W (1985) The effects of ureatreated straw on growth and milk production of crossbred Holstein Friesian dairy cattle. In:The utilization of fibrous agricultural residues as animal feeds (PT Doyle, ed) School of Agric and Forest, Univ of Melbourne, Parkville, Victoria, 88-93

Saadullah M, Haque M, Dolberg $F$ (1981) Effectiveness of ammonication through urea in improving the feeding value of rice straw in ruminants. Trop Anim Prod 6, 30-36

Saadullah M, Haque M, Dolberg F (1982) Treated and untreated rice straw for growing cattle. Trop Anim Prod 7, 20-25

Saadullah M, Haque M, Dolberg F (1983) Effect of chemical treatment of rice straw supplemented with concentrate on feed intake and weight gain in growing calves. In: The utilization of fibrous agricultural residues (GR Pearce, ed) Austr Govern Publ Serv, Canberra,129-139

Sahnoune $S$ (1990) Le traitement des pailles à l'ammoniac produit par l'hydrolyse de l'urée. Thèse de Doctorat, Univ Blaise Pascal, UER Sci Clermont, $117 \mathrm{p}$

Sansoucy R (1986) Manufacture of molasses-urea blocks. World Anim. Rev 57, 40-48

Sansoucy $R$ (1995) New development in the manufacture and utilization of multinutrient blocks. World Anim. Rev 82, 78-83

Schiere JB, Ibrahim MNM (1989) (eds) Feeding of urea ammonia treated rice straw. A compilation of miscellaneous reports produced by the Straw. Utilization Project (Sri-Lanka), Pudoc, Wageningen, $125 \mathrm{p}$

Speedy A, Pugliese PL (1992) (eds) Legume trees and other fodder trees as protein sources for livestock. Proc FAO Expert Consultation Malaysian Agri Res Dev Inst, Kuala Lumpur, FAO Anim Prod Health Paper 102, $339 \mathrm{p}$

Station de recherche Zootechnique du Sahel-NIONO -MALI (1993) Résultats de recherche sur l'utilisation du bloc mélasse - urée en supplémentation chez le zébu et le mouton du 
Sahel. Réunion Comité Techn Rég Rech Agron, Segon

Sudana IB, Leng RA (1986) Effect of supplementing a wheat straw diet with urea or a urea-molasses block and/or cotton seed meal on intake and live-weight change of lambs. Anim Feed Sci Technol 16, 25-35

Sundstol F, Coxworth EM, Mowat DM (1978) Improving the nutritive value of straws and other low quality roughages by treatment with ammonia. World Anim Review 26, 13-21

Sundstol F, Owen E (1984) (ed) Straw and other byproducts as feed. Elsevier, Amsterdam, $604 \mathrm{p}$

Tiwari SP, Singh UB, Usha Mehra R (1990) Urea molasses mineral blocks as feed supplement: effect on growth and nutrient utilization in buffalo calves. Anim Feed Sci Technol 29, 333-341

Tuah AK, Lufadeju E, Orskov ER (1986) Rumen degradation of straw. 1. Untreated and ammoniatreated barley, oat and wheat straw varieties and triticale straw. Anim Prod 43, 261-269

Wanapat M (1994) Supplementation of straw based diets for ruminants in Thailand. In: Proc 7 th AAAP Cong on Improving animal production systems based on local feed resources (A Djajanegara, A Sukmawati, eds) Denpasa, Bali, Indonesia

Wanapat $M$, Praserdsuk $S$, Chanthai $S$, Sivapraphagon A (1982) Effects on rice straw utilization of treatment with ammonia released from urea and or supplementation with cassava chips. In:The utilization of fibrous agricultural residues as animal feeds (PT Doyle, ed) School of Agric and Forest, Univ of Melbourne, Parkville, Victoria,95-101

Wanapat M, Sriwattanasombat $P$, Chanthai S (1984) The utilization of diets containing untreated rice straw, urea-ammonia treated rice straw and water hyacinth. In:The utilization of fibrous agricultural residues as animal feeds (PT Doyle, ed) School of Agric and Forest, Univ of Melbourne, Parkville, Victoria, 155-165
Wanapat $M$, Sommart K, Ajsuk $P$, Wachirapakorn $C$, Toburan W (1992) Effects of high quality feed block supplementation on intake, ruminal fermentation pattern, degradability in ruminants fed rice straw based diets. In: 30 th Annual Meeting, Kasetsart Univ, Bangkok, Thailand

Wanapat M, Sommart K (1993) Supplementation of high quality feed blocks (HQFB) in dairy cows raised by small holder farmers. Depart Anim Sci, Fac Agric, Khon kaern, Thailand (unpublished data)

Wanapat M, Wachirapakorn C, Palanit P, Toburan W (1991) Effects of urea/molasses supplementation and urea-treated rice straw on voluntary feed intake and ruminal fermentation in native cattle fed straw-based diet. In: Proc Utilization of straw in ruminant production systems (DL Romney, ER Ørskov, M Gill, eds) Natur Res Inst, ODA, England

Williams PEV, Innes GM, Brewer A (1984a) Ammonia treatment of straw via hydrolysis of urea. I. Effect of dry matter and urea concentration on the rate of hydrolysis of urea. Anim Feed Sci Technol II, 103-113

Williams PEV, Innes GM, Brever A (1984b) Ammonia treatment of straw via the hydrolysis of urea. IIAdditions of soya bean (urease), sodium hydroxide and molasses. Effects on the digestibility of urea-treated straw. Anim Feed Sci Technol II, 115-124

Wongsrikeao $W$, Wanapat $M$ (1985) The effects of urea treatment of rice straw on the feed intake and liveweight gain of buffaloes. in:The utilization of fibrous agricultural residues as animal feeds (PT Doyle, ed) School of Agric and Forest, Univ of Melbourne, Parkville, Victoria, 81-84

Yameogo-Bougouma V, Cordesse R, Arnaud A, Inesta M (1993) Identification de l'origine des uréases impliquées dans le traitement des pailles de blé à l'urèe et caracteristiques de la flore microbienne présente. Ann Zootech 42, 39-47

Zhang Wei Xian, Jing Kai (1993) Effect of different supplements on production responses and economics of chinese 